\title{
Infantile Spasms: Opportunities to Improve Care
}

\author{
Ricka Messer, MD, PhD ${ }^{1}$ Kelly G. Knupp, MD, MSCS ${ }^{1}$ \\ ${ }^{1}$ Department of Pediatrics and Neurology, University of Colorado, \\ Aurora, Colorado \\ Semin Neurol 2020;40:236-245. \\ Address for correspondence Kelly G. Knupp, MD, MSCS, Department \\ of Pediatrics and Neurology, University of Colorado, Anschutz \\ Campus, 13123 E 16th Avenue, Box 155, Aurora, CO 80045 \\ (e-mail: Kelly.Knupp@childrenscolorado.org).
}

Abstract
Keywords
- infantile spasms
- West syndrome
- adrenocorticotropic
hormone
- prednisolone
- vigabatrin

Infantile spasm (IS) is a distinct epilepsy syndrome characterized by epileptic spasms (the clinical seizure type) and hypsarrhythmia (the electrographic abnormality). IS is frequently accompanied by impaired neurodevelopment and is often associated with structural, genetic, or metabolic etiologies. Prompt treatment of this severe epileptic encephalopathy improves long-term outcomes but remains elusive in many situations. Despite common misconceptions, even patients with identified etiologies or preexisting developmental delay benefit from proven standard therapies, including adrenocorticotropic hormone (ACTH), oral corticosteroids, or vigabatrin. Treatment efficacy should be assessed with electroencephalography at 2 weeks, and an alternative therapy is indicated if epileptic spasms or hypsarrhythmia have not resolved. Collaboration with primary care providers is critical to mitigate the potentially serious adverse effects of standard treatments and also to provide developmental interventions. Although new approaches are on the horizon, addressing current challenges and opportunities now can dramatically improve patient outcomes.
Infantile spasm (IS) is a severe epileptic encephalopathy of early childhood that was first described in $1841 .{ }^{1}$ Historically, the classic triad of West syndrome included clinical seizures (epileptic spasm, ES), an abnormal interictal electroencephalogram (EEG) pattern (hypsarrhythmia), and developmental issues. However, developmental delay and hypsarrhythmia are not always present at onset, which the International League Against Epilepsy (ILAE) seizure classification and West Delphi Consensus Statement recognized with broader definitions of IS, West syndrome, ES, and hypsarrhythmia (- Table 1). ${ }^{2,3}$ The diagnosis of IS requires both a high index of suspicion and a prolonged EEG, and many resources are available to educate the public and providers about this unusual seizure type (-Fig. 1). Perhaps more than any other epilepsy syndrome, short- and long-term outcomes are influenced by time to treatment and choice of treatment. This review will highlight several opportunities for improvements in the care of children with IS (-Table 2 ).

Though one of the most common epilepsies of early childhood, IS has an incidence of only 0.01 to $0.58 / 1,000$ live births. $^{4-7}$ IS predominately affects children less than 2 years of age, with a peak onset of 3 to 7 months and only rare reports of age of onset up to 4 years of age..$^{8-12}$ The epidemiology of IS has been evaluated in several different populations, and a recent meta-analysis suggests that latitude may impact the incidence, but importantly, data from lower latitudes are scarce. ${ }^{5}$ Gender differences have also been debated, though most studies suggest a slight preponderance in boys compared with girls.

\section{Seizure Description}

Like other seizure types, ESs are paroxysmal, involuntary, repetitive, abnormal movements. The semiology is unique, with sudden contraction of the trunk and extremities lasting less than 1 second, but often occurring in clusters (- Table 3 ). ESs are frequently associated with sleep-wake transitions. Consciousness is not impaired, but the child may briefly cry or appear distressed after each spasm. Mimickers of ES include normal baby movements, exaggerated startle reflex, Sandifer syndrome (abnormal movements provoked by gastroesophageal reflux), benign sleep myoclonus, myoclonic seizures, focal seizures, and tonic seizures. ${ }^{13,14}$
Issue Theme Pediatric Neurology; Guest Editors, Kendall B. Nash, MD, and Nilika Shah Singhal, MD
Copyright $\odot 2020$ by Thieme Medical Publishers, Inc., 333 Seventh Avenue, New York, NY 10001, USA. Tel: +1(212) 760-0888. ISSN $0271-8235$. 
Table 1 Proposed definitions of terms, modified from West Delphi Consensus and ILAE ${ }^{3,92}$

\begin{tabular}{|l|l|l|}
\hline Term & Definition & Additional information \\
\hline $\begin{array}{l}\text { Infantile } \\
\text { spasm (IS) }\end{array}$ & $\begin{array}{l}\text { The epilepsy syndrome-children younger than } \\
\text { 2 y with epileptic spasms, with or without } \\
\text { hypsarrhythmia }\end{array}$ & $\begin{array}{l}\text { Within the ILAE 2017 epilepsy classification, IS is an } \\
\text { epileptic encephalopathy caused by various } \\
\text { etiologies }\end{array}$ \\
\hline $\begin{array}{l}\text { West } \\
\text { syndrome (WS) }\end{array}$ & $\begin{array}{l}\text { The constellation of epileptic spasms and } \\
\text { hypsarrhythmia, with or without developmental } \\
\text { issues }\end{array}$ & $\begin{array}{l}\text { Historically, developmental issues were a defining } \\
\text { feature of WS, named after the first person to } \\
\text { recognize the constellation of symptoms which } \\
\text { were affecting his own child }\end{array}$ \\
\hline $\begin{array}{l}\text { Epileptic } \\
\text { spasm (ES) }\end{array}$ & The seizure type & $\begin{array}{l}\text { The term "ES" is preferable to the term IS when } \\
\text { referring to the clinical seizures. ES can have focal } \\
\text { motor onset, generalized motor onset, or unknown } \\
\text { motor onset, but do not require a specified } \\
\text { awareness }\end{array}$ \\
\hline $\begin{array}{l}\text { Hypsarrhythmia } \\
\text { "hyps") }\end{array}$ & The abnormal interictal EEG pattern & $\begin{array}{l}\text { This random, high-voltage pattern was first } \\
\text { described by Gibbs and Gibbs in 1952 }\end{array}$ \\
\hline
\end{tabular}

Abbreviations: EEG, electroencephalogram; ILAE, International League Against Epilepsy.

\section{Electroencephalogram Findings}

Prolonged EEG is required for the diagnosis of IS and helps differentiate between IS mimics. The characteristic EEG background pattern is hypsarrhythmia (-Fig. 2)-chaotic, asynchronous, and high-amplitude activity (often greater than 200 microvolts) with intermixed multifocal spikes. ${ }^{15}$ Although hypsarrhythmia is considered a biomarker of IS, disagreement about the defining characteristics continues, ${ }^{3,16}$ despite standardized grading tools focusing on quantifiable features such as the Burden of Amplitudes and Epileptiform Discharges (BASED) score ( Table 4). ${ }^{17}$ The BASED score creates an objective scale to determine the features of hypsarrhythmia and has been shown to improve inter-rater reliability. Hypsarrhythmia is most likely to be seen during non-REM sleep. Most, but not all, children with ES have hypsarrhythmia; studies report 52\% 18 to $100 \%{ }^{8,19-21}$ This variation is primarily due to inclusion of variants of hypsarrhythmia. ${ }^{22}$ When hypsarrhythmia is not present, the EEG pattern is still markedly abnormal. If spells are not captured on the EEG, repeat EEG may be warranted if concerning spells continue to occur. Parental video of the spells may also help clarify the diagnosis.

During the seizure, the ictal EEG has a distinctive, diffuse high-amplitude slow wave with superimposed fast activity, followed by electrodecrement (diffuse attenuation), which may appear to be more normal activity (-Fig. 3). This "pseudo-normalization" can lasts for several seconds, even minutes. In addition to IS, other epilepsy syndromes, such as Ohtahara syndrome or early infantile myoclonic epilepsy, may have ES as

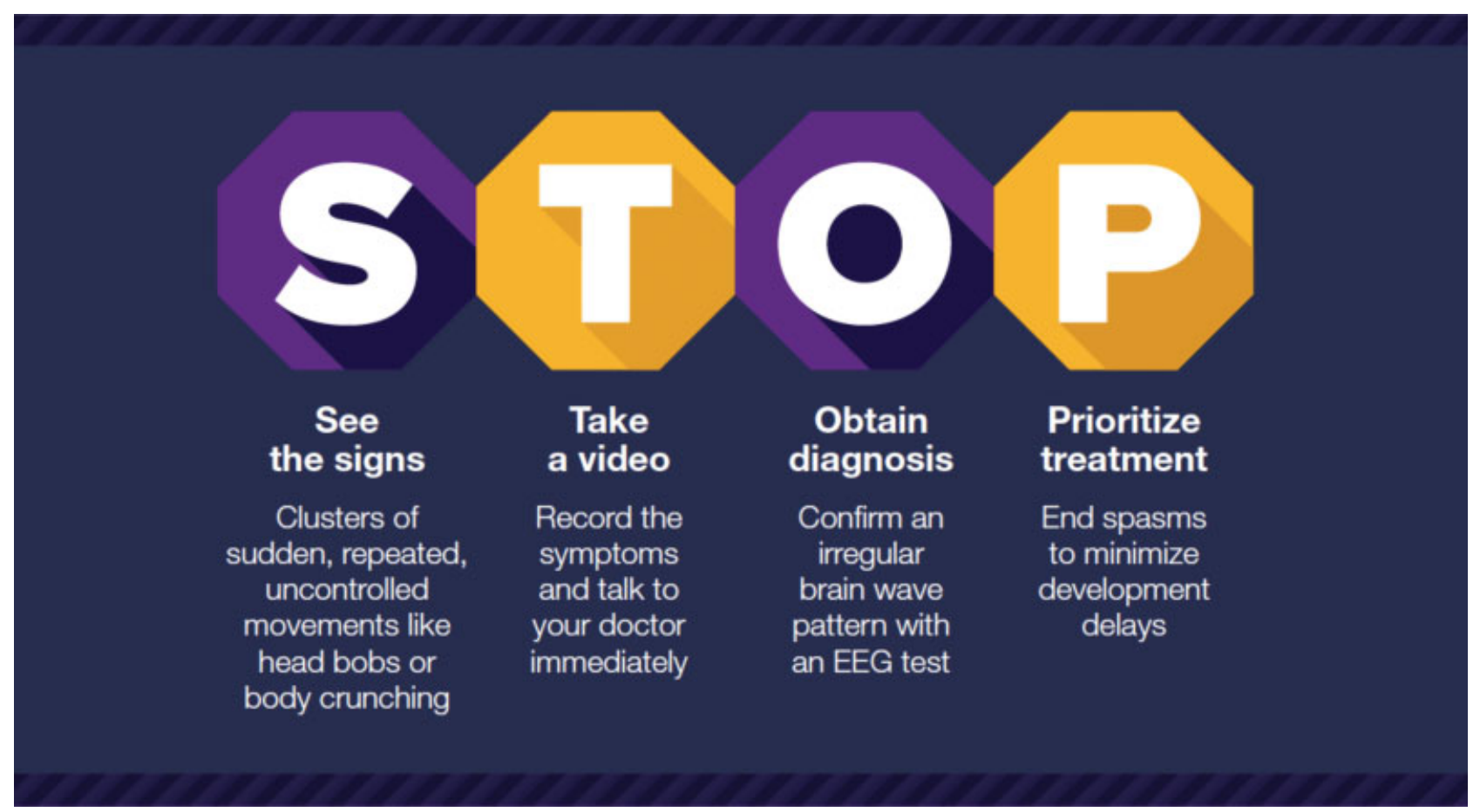

Fig. 1 Pneumonic developed by the Infantile Spasms Action Network to improve awareness of infantile spasms. 
Table 2 Key opportunities and goals for improving the care of patients with IS

\begin{tabular}{|c|c|}
\hline Opportunity & Goal \\
\hline 1. Make the diagnosis early ${ }^{\mathrm{a}, \mathrm{b}, \mathrm{c}, \mathrm{d}}$ & Evaluate with prolonged EEG within 1-2 wk of symptom onset \\
\hline 2. Initiate treatment early ${ }^{a, b, c, d, e}$ & Initiate treatment within $1 \mathrm{wk}$ of diagnosis \\
\hline 3. Investigate the etiology ${ }^{a, c, d}$ & Perform brain MRI within 4 wk of diagnosis; consider tiered genetic/metabolic testing \\
\hline $\begin{array}{l}\text { 4. Choose a standard first-line } \\
\text { treatment }{ }^{a, b, c, d, e, f, g}\end{array}$ & Treat with ACTH, oral corticosteroids, or vigabatrin (see - Table 5) \\
\hline $\begin{array}{l}\text { 5. Mitigate adverse side effects } \\
\text { of treatments }{ }^{\mathrm{a}, \mathrm{c}, \mathrm{e}, \mathrm{g}}\end{array}$ & $\begin{array}{l}\text { Monitor for hypertension and infection at least weekly (ACTH, OCS); obtain } \\
\text { ophthalmologic evaluation every } 3 \text { mo (vigabatrin); see - Table } 6\end{array}$ \\
\hline $\begin{array}{l}\text { 6. Assess treatment } \\
\text { efficacy }{ }^{\mathrm{a}, \mathrm{b}, \mathrm{c}, \mathrm{d}, \mathrm{e}, \mathrm{g}}\end{array}$ & $\begin{array}{l}\text { Confirm that both clinical spasms and hypsarrhythmia have resolved with } \\
\text { follow-up EEG at } 2-3 \mathrm{wk}\end{array}$ \\
\hline $\begin{array}{l}\text { 7. Change treatments if } \\
\text { response is incomplete } e^{\mathrm{a}, \mathrm{c}, \mathrm{d}}\end{array}$ & $\begin{array}{l}\text { Switch to an alternative standard treatment. For IS refractory to two standard } \\
\text { treatments, consider surgery and/or additional treatments } \\
\text { (pyridoxine, ketogenic diet, typical antiseizure mediations) }\end{array}$ \\
\hline $\begin{array}{l}\text { 8. Monitor developmental } \\
\text { outcomes } s^{c, d, e, g}\end{array}$ & Refer to early intervention services; assess every 6 mo \\
\hline
\end{tabular}

Abbreviations: ACTH, adrenocorticotropic hormone; EEG, electroencephalogram; ILAE, International League Against Epilepsy; IS, infantile spasm. Sources for opportunities:

${ }^{a}$ U.S. Consensus Report. ${ }^{29}$

${ }^{b}$ AAN/CNS Guideline. ${ }^{37}$

'Quality of Care Indicators. ${ }^{27}$

dILAE Recommendations. ${ }^{30}$

${ }^{\mathrm{e} A A N}$ Quality Measures. ${ }^{28}$

${ }^{f}$ Cochrane Review. ${ }^{38}$

${ }^{9}$ AAN/CNS Practice Parameter MacKay. ${ }^{36}$

Table 3 Distinguishing features of various types of clinical spasms

\begin{tabular}{|l|l|}
\hline Clinical spasm type & Distinguishing features \\
\hline $\begin{array}{l}\text { Flexor spasms } \\
\text { "JJackknife seizures”) }\end{array}$ & $\begin{array}{l}\text { The child may appear to do an abdominal "crunch"-the neck and trunk suddenly flex, } \\
\text { the knees are pulled up, and the arms either come in toward the chest or, } \\
\text { more commonly, stiffen and are flung outward }\end{array}$ \\
\hline Extensor spasms & $\begin{array}{l}\text { The child may throw the head back, arch the back, and stiffen and extend } \\
\text { the arms and legs }\end{array}$ \\
\hline Mixed extensor-flexor spasms & The child may show features of both types \\
\hline Hemi-spasms & Only one side of the body is affected \\
\hline Asymmetric spasms & $\begin{array}{l}\text { These may mimic the asymmetric tonic posture reflex or otherwise affect the two sides } \\
\text { of the body differently }\end{array}$ \\
\hline Subtle spasms & $\begin{array}{l}\text { The child may demonstrate isolated forceful head bobs, facial grimace, eye rolling, } \\
\text { eye deviation, or brief staring }\end{array}$ \\
\hline
\end{tabular}

a seizure type, but these disorders have other EEG features, as well as a more concerning prognosis.

\section{Early Diagnosis and Treatment Impact Developmental Outcomes-Opportunities 1 and 2}

Onset of ES is frequently preceded by developmental delays, plateau, or regression. A recent study found $90 \%$ of infants with IS had developmental delay at the time of presentation. ${ }^{23}$ More than half had impaired social responsiveness, such as absent social smile, as well as auditory impairments, including poor response to voice. In addition, $44 \%$ displayed visual inattention, which caregivers may notice as a decrease in eye contact or tracking. Over time, the developmental impact becomes more pronounced, and the child may lose head control, stop sitting, and become less interactive.

Fortunately, timely treatment, particularly within 7 to 30 days of ES onset, is associated with improved response to treatment and neurodevelopmental outcomes. ${ }^{13,24-26}$ Thus, consensus quality improvement guidelines strongly recommend evaluation with prolonged EEG and treatment initiation as soon as possible, certainly within 1 to 2 weeks of presentation. $^{27-30}$

\section{Take a Step-Wise Approach to the Etiologic Investigation-Opportunity 3}

After the diagnosis of IS has been established, the etiology should be investigated, particularly since some causes may 


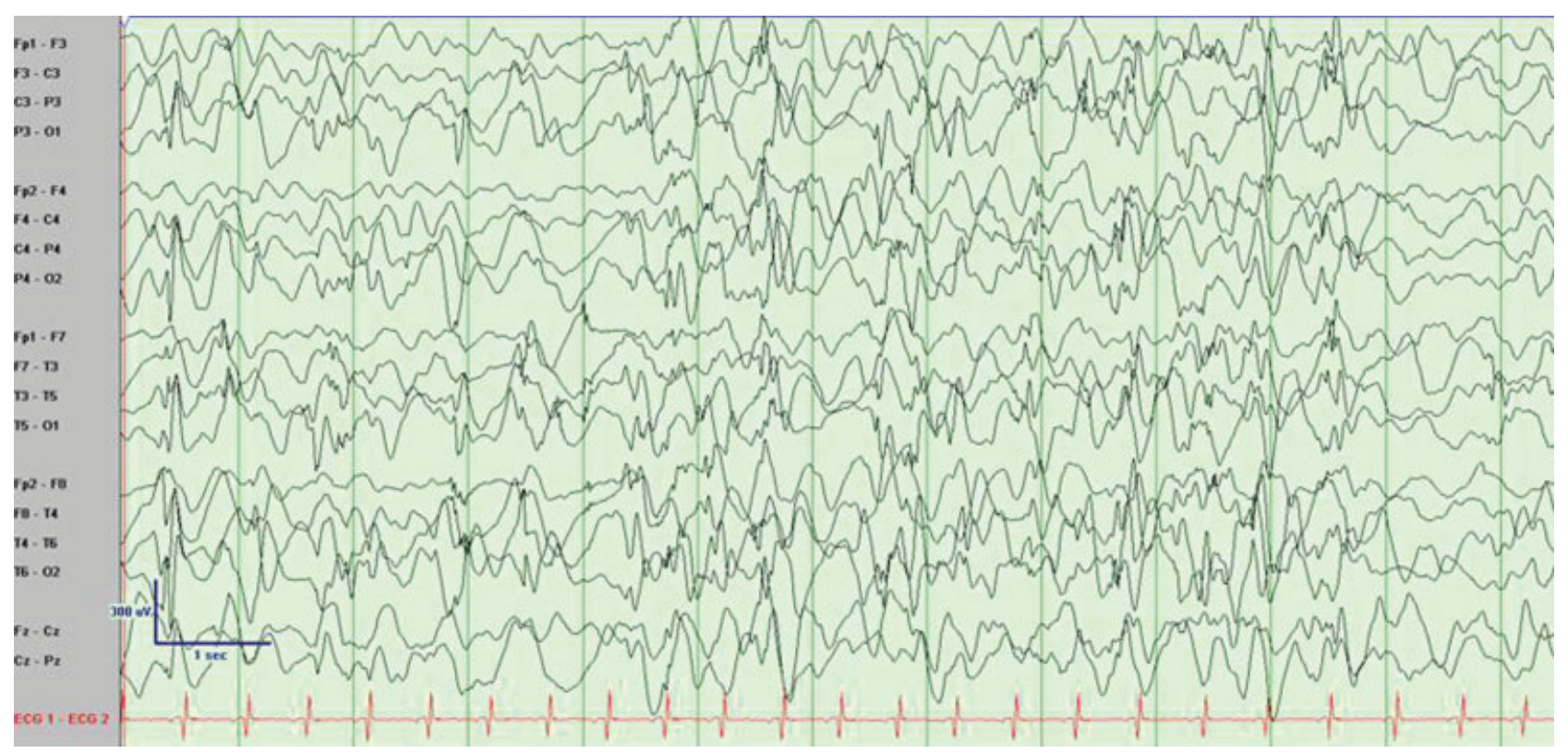

Fig. 2 Example of hypsarrhythmia.

Table 4 BASED score ${ }^{17}$

\begin{tabular}{|c|c|}
\hline BASED score & Description \\
\hline 0 & Normal \\
\hline 1 & Any definite nonepileptiform abnormality \\
\hline 2 & $<3$ spike foci and no common background slow waves $\geq 200 \mu v^{\mathrm{a}, \mathrm{b}}$ \\
\hline 3 & $\begin{array}{l}\text { MFS }<50 \% \text { of one second bins }{ }^{c} \text { and no common background slow waves } \geq 200 \mu \mathrm{v} \text {, }{ }^{\mathrm{a}, \mathrm{b}} \text { or } \\
\text { no MFS but common background slow waves } \geq 200 \mu \mathrm{v}^{\mathrm{a}, \mathrm{b}}\end{array}$ \\
\hline $4\left(\right.$ Hyps $\left.^{\mathrm{d}}\right)$ & MFS $<50 \%$ of one second bins ${ }^{c}$ and common background slow waves $\geq 200 \mu \mathrm{v}^{\mathrm{a}, \mathrm{b}}$ \\
\hline $5\left(\right.$ Hyps $\left.^{d}\right)$ & $\begin{array}{l}\text { MFS } \geq 50 \% \text { of one second bins, }{ }^{\mathrm{c}} \text { or } \\
\text { Common background slow waves } \geq 300 \mu \mathrm{v}^{\mathrm{a}, \mathrm{e}} \text { in two or more bilateral head regions }\end{array}$ \\
\hline
\end{tabular}

Abbreviations: BASED, Burden of Amplitudes and Epileptiform Discharges; MFS, multifocal spikes-at least three different foci; $\mu \mathrm{v}$, microvolts. aPeak-to-peak amplitude on a longitudinal bipolar montage, refers to background slow waves and excludes (1) the slow wave associated with a preceding spike, (2) hypnagogic patterns, and (3) arousal rhythms.

${ }^{b}$ May be one or more head regions, must be a common finding, may be regional (e.g., left posterior), and may exist in the presence of other lower amplitude background activities.

${ }^{\mathrm{C}}$ The percentage of one second bins that include one or more spikes in the most severely abnormal 5-minute epoch (i.e., the epoch that gives the highest BASED score).

${ }^{\mathrm{d}}$ To determine the presence or absence of hypsarrhythmia, findings should be representative of the most severely abnormal 5-minute epoch of the study (i.e., the epoch that gives the highest BASED score); a score of 4 or 5 suggests electrographic evidence of hypsarrhythmia.

${ }^{\mathrm{e}}$ Must be two of the following: bilateral frontal, bilateral temporal, bilateral parietal, and bilateral occipital; must be a common finding.

benefit from specialized treatment ( - Table 5). ${ }^{27,29-31}$ Many speculate that brain dysfunction from essentially any cause early in life may converge into a "final common pathway" that ultimately results in the development of IS. Indeed, more than 200 conditions are known to be associated with IS.

The combination of history, physical exam, and early imaging yields a diagnosis in 40 to $55 \%$ of cases. ${ }^{32,33}$ Patients with disorders such as tuberous sclerosis complex, Trisomy 21, and Menkes disease have high rates of IS, and may have notable physical exam findings, such as ash leaf spots (identified most easily with a Wood's lamp), syndromic facies, or unusually brittle hair. Structural causes, such as brain malformations, traumatic brain injury, hypoxic-ischemic encephalopathy, and congenital cytomegalovirus account for roughly $40 \%$ of cases, including 20\% with acquired brain injury. ${ }^{32-34}$ Thus, brain MRI is strongly recommended for the initial diagnostic evaluation of patients with IS, and additional testing can be deferred, unless syndromic features, concerning symptoms, or metabolic derangements are also present.

If imaging is uninformative, chromosomal microarray/comparative genomic hybridization, followed by an epilepsy gene panel if needed, as well as serum lactate, serum amino acids, and urine organic acids are recommended. Genetic testing demonstrates an etiology in $23 \%$ of those without imaging findings. $^{32}$ Various inborn errors of metabolism, including GLUT1 deficiency, pyridoxine-dependent seizures, phenylketonuria, nonketotic hyperglycinemia, and methylmalonic aciduria continue to be reported as rare but potentially treatable 


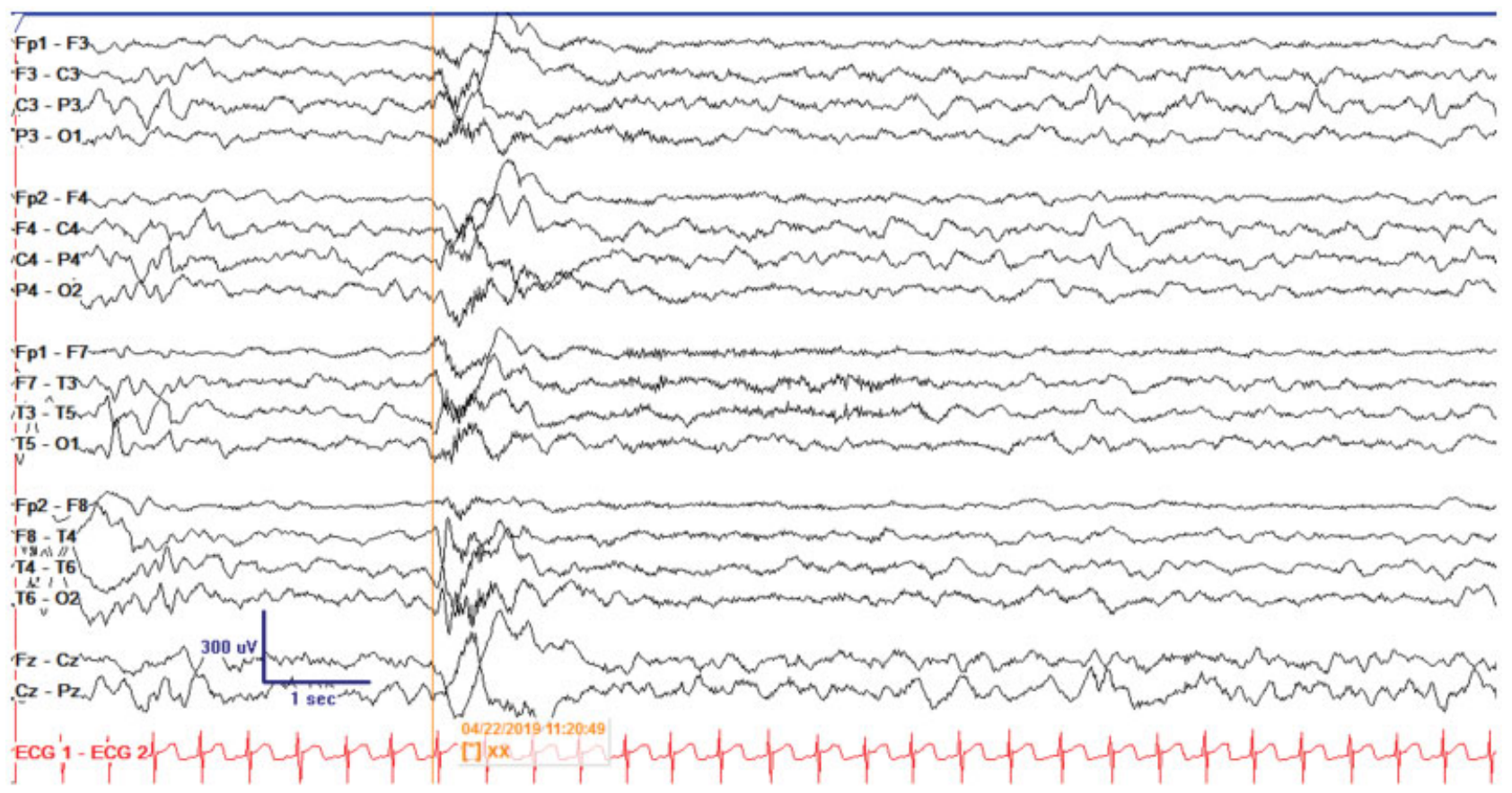

Fig. 3 Example of electroencephalogram findings during an epileptic spasm.

Table 5 Comparison of standard first-line IS treatments

\begin{tabular}{|c|c|c|c|}
\hline Treatment & Efficacy & Logistics & Side effects (see - Table 6 ) \\
\hline ACTH & $\begin{array}{l}\text { ILAE: "preferred treatment" } \\
\text { Short-term response: } 76-87 \% \\
\text { 3-mo response: } 55 \% \\
\text { Risk of relapse: likely less }\end{array}$ & $\begin{array}{l}\text { Cost: } \$ \$ \$+\text { admission } \\
\text { Dosing: intramuscular injections, } \\
150 \text { units } / \mathrm{m}^{2} / \mathrm{d} \text { for } 2 \mathrm{wk}, 2 \text {-wk taper } \\
\text { Other: specialty pharmacy }\end{array}$ & \multirow{2}{*}{$\begin{array}{l}\text { Mild-moderate: irritability, } \\
\text { increased appetite, weight gain, } \\
\text { poor sleep, } \\
\text { stomach ulcers, hypertension, } \\
\text { hyperglycemia } \\
\text { Severe: infection, cardiomyopathy, } \\
\text { adrenal crisis }\end{array}$} \\
\hline $\begin{array}{l}\text { Oral } \\
\text { corticosteroids } \\
\text { (prednisolone) }\end{array}$ & $\begin{array}{l}\text { ILAE: "probably effective" } \\
\text { Short-term response: } 63-80 \% \\
\text { 3-mo response: } 39 \% \\
\text { Risk of relapse: possibly } \\
\text { higher than ACTH }\end{array}$ & $\begin{array}{l}\text { Cost: } \$ \text {, no admission } \\
\text { Dosing: oral liquid, } 4-8 \mathrm{mg} / \mathrm{kg} / \mathrm{d} \\
\text { (max } 60 \mathrm{mg} \text { ) for } 2 \mathrm{wk}, 2 \text {-wk taper } \\
\text { Other: any retail pharmacy }\end{array}$ & \\
\hline Vigabatrin & $\begin{array}{l}\text { ILAE: "possibly effective, } \\
\text { especially for TSC" } \\
\text { Short-term response: } 35-54 \% \\
\text { 3-mo response: } 36 \% \\
\text { Risk of relapse: } \\
\text { higher than ACTH }\end{array}$ & $\begin{array}{l}\text { Cost: } \$ \$+/- \text { admission } \\
\text { Dosing: powder mixed into oral liquid, } \\
\text { increased from } 50 \text { to } 150 \mathrm{mg} / \mathrm{kg} / \mathrm{d} \text { over } \\
714 \mathrm{~d} \text {, then } 3-12 \text { mo } \\
\text { Other: specialty pharmacy and } \\
\text { REMS enrollment }\end{array}$ & $\begin{array}{l}\text { Mild-moderate: poor sleep, } \\
\text { drowsiness, hypotonia, behavioral } \\
\text { changes, reversible MRI changes } \\
\text { Severe: irreversible peripheral } \\
\text { vision loss }\end{array}$ \\
\hline
\end{tabular}

Abbreviations: ACTH, adrenocorticotropic hormone; ILAE, International League Against Epilepsy; REMS, Risk Evaluation and Mitigation Service; TSC, tuberous sclerosis.

causes of IS, although patients with the newly recognized "ISassociated gene" disruptions, such as ARX (Aristaless-related homeobox) and CDKL5 (cyclin-dependent kinase-like 5), and STXBP1 (syntaxin-binding protein 1 ), may be much more likely to develop IS. ${ }^{31,35}$ Third/fourth tier testing could include novel gene testing or repeat brain MRI, since advances in genetic technology occur rapidly, and ongoing myelination may permit visualization of small abnormalities. Despite exhaustive evaluations, a definitive etiology is not found in 30 to $50 \%$ of children.

\section{Offer an Effective Standard Treatment- Opportunity 4}

Unlike other epilepsy types, the efficacy of IS treatment is determined with an "all-or-none" approach that requires both cessation of ES and resolution of hypsarrhythmia, thus requiring a repeat EEG within 2 to 3 weeks of treatment initiation. ${ }^{3,27,36}$ Partial reduction of ES frequency or cessation of ES with persistence of hypsarrhythmia is considered treatment failure.

IS responds poorly to typical antiseizure medications. Currently, adrenocorticotropic hormone (ACTH), oral corticosteroids (OCS), and vigabatrin are the only identified "possibly" or "probably effective" therapies for IS (- Table 5). ${ }^{28,30,37}$ Importantly, comparing treatment efficacy has been confounded by evolving dosing regimens and outcome measures, and most guidelines were published prior to several recent clinical studies. Although the 2012 American Academy of Neurology/Child Neurology Society guidelines found insufficient evidence to support short-term efficacy of OCS, they agreed with the ILAE 
consensus and Cochrane review that hormonal treatment with either ACTH or OCS improved long-term outcomes compared with vigabatrin, particularly for children with an unknown etiology. ${ }^{30,37,38}$ Furthermore, increasing the percentage of children with IS who receive ACTH, OCS, or vigabatrin as a first-line agent was identified as a key quality improvement metric by the 2018 Child Neurology Quality Measurement Set Workgroup. ${ }^{28}$ The 2016 National Infantile Spasms Consortium (NISC) observational study of more than 230 patients found that the most important determinant of response to treatment was utilizing any one of these three treatments as the first-line agent, regardless of etiology, prior developmental delay, or presence of hypsarrhythmia. ${ }^{20,39}$

\section{Steroid/Hormonal Treatments (ACTH and OCS)}

Steroid/hormonal medications, including ACTH and OCS, have been used since the 1950 s. $^{40,41}$ Some speculate that the hypothalamic-pituitary-adrenal axis is dysregulated in the pathophysiology of IS, possibly due to stress, and that ACTH may have additional neuromodulatory properties compared with OCS. ${ }^{42,43}$ Synthetic and naturally derived ACTH have similar efficacy, with 2-week response rates of 76 to $87 \%$ in controlled trials, though a direct comparison has not occurred. ${ }^{44,45}$ The high cost and poor availability of ACTH have fueled the pursuit of alternative hormonal treatments, including OCS, though the comparative efficacy between ACTH and OCS is debated. Early studies using low-dose OCS (1-2 mg/kg/day) demonstrated inferior efficacy compared with $\mathrm{ACTH},{ }^{45,46}$ whereas recent studies of high-dose OCS (4-8 mg/ $\mathrm{kg} /$ day) have found response rates of 63 to $80 \%$, similar to ACTH. ${ }^{44,47-49}$

\section{Vigabatrin}

Vigabatrin is a specific inhibitor of gamma-aminobutyric acid transaminase (GABA-T), the enzyme responsible for metabolizing GABA at the synapse. Short-term response rates to vigabatrin range from 35 to $54 \%$, significantly lower than hormonal treatments; however, the 14-day assessment point of most studies may not sufficiently account for the longer titration period of vigabatrin. ${ }^{44,50-53}$ Although longterm outcomes were similar between vigabatrin and hormonal treatments across all etiologies, hormonal therapies were associated with improved development in children with unknown etiologies. ${ }^{54}$ Interestingly, in patients with tuberous sclerosis complex, vigabatrin is more efficacious than steroids and is, therefore, the treatment of choice. ${ }^{51,55}$

\section{Alternative Treatments}

Although other IS treatments have been investigated, in general, these studies have small sample sizes, inadequate primary outcome measures, or lack of randomization. Some therapies show promise as first-line treatment when standard treatment options are not possible. A small prospective study of the ketogenic diet as initial treatment for IS demonstrated a 2-week clinical response rate of 56\%, all of whom had normal EEGs at 6 months. ${ }^{56}$ The efficacy of pyridoxine as a first-line agent has not been clearly established, despite frequent use at some centers. Early studies with topiramate showed a 28 to
$45 \%$ response rate at 3 months; however, a newer study found only a $9.7 \%$ response rate, and all relapsed. ${ }^{57-59}$ Interestingly, a recent randomized controlled study of zonisamide found a $20 \%$ clinical and electrographic response rate at 2 weeks. ${ }^{60}$ Other typical antiseizure medications have been trialed throughout the years. Two small prospective studies found levetiracetam was effective in 14 to $40 \%$ of patients. ${ }^{61,62}$ A retrospective study of sodium valproate with or without a benzodiazepine demonstrated ES cessation in $45.8 \%,{ }^{63}$ though use of valproate acid is often avoided in young children due to concern for POLG pathogenic variants. Overall, the NISC study grouped all nonstandard treatments, including the ketogenic diet, topiramate, zonisamide, clobazam, clonazepam, valproic acid, phenobarbital, oxcarbazepine, and levetiracetam, into a single "other" category, and found response rates of $22 \%$ at 2 weeks and only $9 \%(3 / 32)$ at 3 months. $^{39}$

\section{Mitigate the Side Effects of Treatments-Opportunity 5}

All three standard treatments carry significant risk of serious side effects (- Table 5). ${ }^{36}$ The Children's Hospital Colorado clinical pathway outlines one institution's approach to recommended surveillance and treatment (-Table $\mathbf{6}$ ). In some studies, more than half of patients with IS treated with steroid/hormonal medications experienced adverse effects, such as irritability, hypertension, and infection, which may require medical intervention. ${ }^{48,64}$ Although 34 to $52 \%$ of all patients treated with vigabatrin were found to have permanent visual field loss, the incidence of clinically significant visual impairment may be less than $4 \%$ in the IS population. ${ }^{65-67}$ Nonetheless, in the United States, vigabatrin initiation requires enrollment in a Risk Evaluation and Mitigation Service (REMS) program, and frequent ophthalmologic evaluations are recommended. Some concerns remain about the clinical significance of vigabatrin-associated reversible MRI changes, though these have not been definitively associated with any symptom, including movement disorders. ${ }^{64,68,69}$

\section{Assess Treatment Efficacy and, if Needed, Switch to an Alternative Treatment- Opportunities 6 and 7}

Prolonged repeat EEG 2 to 3 weeks after treatment initiation is strongly recommended. ${ }^{27,29}$ If ES or hypsarrhythmia persists, then the first medication should be weaned while a second medication is started. ${ }^{27}$ The NISC study found that children who failed an initial standard treatment had a 55\% response rate when given another standard treatment with a different mechanism of action. ${ }^{26} \mathrm{~A}$ similar approach is likely warranted for IS recurrence, defined as recurrence of ES, which occurs in 30 to $50 \%$ of patients.

The best approach after two standard medications have failed is not clear, but in general, additional therapy trials and ongoing reassessment of efficacy are recommended. ${ }^{30,70}$ The ketogenic diet is another important consideration, with one study demonstrating a $37 \%$ clinical response rate at 6 months, most of who had failed standard treatments. ${ }^{56}$ Typical 
Table 6 Strategies for mitigating side effects of hormonal treatments and vigabatrin

\begin{tabular}{|c|c|}
\hline Hormonal treatments & \\
\hline $\begin{array}{l}\text { Irritability, increased appetite, } \\
\text { and poor sleep }\end{array}$ & Provide anticipatory guidance and coping strategies \\
\hline $\begin{array}{l}\text { Complex treatment plan and } \\
\text { high risk of side effects }\end{array}$ & $\begin{array}{l}\text { Neurology nurse phone call within } 1 \mathrm{wk} \\
\text { Primary care provider monitors weight, blood/urine glucose, and hypertension } \\
\text { (defined as SBP }>95 \text { th } \% 3 \text { d) twice a week }\end{array}$ \\
\hline Stomach irritation/ulcer & $\begin{array}{l}\text { Prescribe histamine blockers (such as ranitidine) or proton pump inhibitors } \\
\text { (such as omeprazole) for duration of treatment }\end{array}$ \\
\hline $\begin{array}{l}\text { Infection-Part 1: } \\
\text { Pretreatment screening }\end{array}$ & $\begin{array}{l}\text { Assess for any signs/symptoms of infection. If the patient has tuberculosis risk factors, place } \\
\text { purified protein derivative skin test (Quantiferon gold is not accurate in infants) }\end{array}$ \\
\hline $\begin{array}{l}\text { Infection: Part 2-During treatment } \\
\text { and for 2-3 mo after }\end{array}$ & $\begin{array}{l}\text { Avoid live vaccines; defer other vaccines if possible. Prescribe antibiotic prophylaxis } \\
\text { (sulfamethoxazole/trimethoprim) } \times 8 \text { wk. Counsel caregivers to avoid sick contacts and monitor } \\
\text { for thrush. Evaluate child immediately for any sick symptoms }\end{array}$ \\
\hline Adrenal suppression & $\begin{array}{l}\text { Consider stress dose steroids for any illness, surgery, or other physical stressor. Provide } \\
\text { caregivers with a letter explaining possible need for stress dose steroids during treatment and } \\
\text { for } 2-3 \text { mo after }\end{array}$ \\
\hline $\begin{array}{l}\text { Hypertension management-Part 1: } \\
\text { Electrolyte disturbances }\end{array}$ & $\begin{array}{l}\text { Obtain electrolyte levels within } 24 \mathrm{~h} \text { of HTN diagnosis. If hypokalemia, alkalosis, or hyper- } \\
\text { natremia is found, obtaining endocrinology input, evaluation for cardiac arrhythmia, and } \\
\text { initiation of a diuretic (rather than propanolol) may be needed }\end{array}$ \\
\hline $\begin{array}{l}\text { Hypertension management-Part 2: } \\
\text { Risk of cardiomyopathy }\end{array}$ & $\begin{array}{l}\text { Initiate propranolol within } 24 \mathrm{~h} \text { of diagnosis of } \mathrm{HTN} \text { and refer patient to nephrology for further } \\
\mathrm{HTN} \text { management. Obtain } \mathrm{ECHO} \text { within } 1 \mathrm{wk} \text {. If ECHO is abnormal, urgent cardiology evaluation } \\
\text { is warranted. Weaning steroids is typically not recommended }\end{array}$ \\
\hline Hyperglycemia management & Refer to endocrinology for possible initiation of insulin \\
\hline \multicolumn{2}{|l|}{ Vigabatrin } \\
\hline Irritability, poor sleep & Provide anticipatory guidance and coping strategies \\
\hline Sedation, lethargy, hypotonia & $\begin{array}{l}\text { Evaluate child immediately if feeding is impacted or caregivers are concerned. Consider } \\
\text { increasing the vigabatrin dose more slowly }\end{array}$ \\
\hline Risk of permanent vision loss & $\begin{array}{l}\text { Enroll child in the REMS program. Obtain ophthalmology evaluation within } 4 \text { wk of treatment } \\
\text { initiation, every } 3 \text { mo during treatment, and } 3 \text { mo after completing treatment. Monitor for signs } \\
\text { of worsening vision, such as being easily startled }\end{array}$ \\
\hline Reversible MRI abnormalities & Counsel caregivers about the potential risk; report possible associated symptoms to REMS \\
\hline
\end{tabular}

Abbreviations: ECHO, echocardiography; HTN, hypertension; MRI, magnetic resonance imaging; REMS, Risk Evaluation and Mitigation Service; SBP, spontaneous bacterial peritonitis.

anticonvulsants, such as topiramate, zonisamide, or clobazam, are often utilized as third- and fourth-line agents. One study evaluated whether topiramate or zonisamide could prevent IS recurrence when given for several months after initial treatment with standard therapies, but found that neither was effective. ${ }^{71}$ Epilepsy surgery has been used with great success in appropriately chosen children with focal etiologies for seizures, but is not recommended as first-line therapy due to the lengthy surgical evaluation process and risks associated with surgical intervention. ${ }^{72,73}$ Children with focal findings on imaging, EEG, and/or asymmetric clinical spasms might be considered as a candidate for surgical evaluation. Corpus callosotomy maybe an option in children without focal imaging abnormalities. ${ }^{74}$ Careful evaluation should occur urgently in an appropriate epilepsy center, as outcome may be improved with earlier treatment.

\section{Improving Long-Term Outcomes- Opportunity 8}

Although short-term efficacy focuses on resolution of ES and hypsarrhythmia, ultimately, the goal of therapy is to improve long-term outcomes, such as neurodevelopment and subsequent epilepsy. Several studies indicate that 11 to $60 \%$ of patients experience other seizure types later in life, ${ }^{19,75-80}$ with almost one-third presenting by the age of 1 year. Evolution into Lennox-Gastaut syndrome has been reported in approximately $25 \%$ of infants with IS; identifying any etiology and children of older age at diagnosis both are known risk factors. ${ }^{10,81,82}$

Intellectual impairment is often the primary concern for both parents and providers. Fewer than $10 \%$ of children with prenatal and perinatal etiologies have normal intellectual outcomes, ${ }^{83}$ compared with 41 to $57 \%$ of those without prior developmental delay and unknown etiologies. ${ }^{19,82,84}$ One long-term study evaluated specific developmental domains, and found $30 \%$ with visual impairment and severe cerebral palsy in $45 \%$, though $42 \%$ of children were able to ambulate. ${ }^{19}$ Psychiatric disorders and autism as long-term outcomes have not been well studied, but one study found psychiatric disorders in $28 \%$ of children. ${ }^{19}$ Autism has been reported in 13 to $33 \% .{ }^{85,86}$ All children with IS should be referred for early intervention evaluation, and many children may benefit from multidisciplinary care from rehabilitation providers, neuropsychologists, 
social work, and developmental pediatricians. ${ }^{87}$ Ongoing improvements in supportive care have already impacted mortality rates in children with IS, which historically reached $15 \%$ by 11 years, but more recent cohorts have reported 5 to $8 \%{ }^{4}$

\section{Recent Updates and Future Directions}

Ongoing research focuses on several aspects of the disease, including identification of IS risk factors, determining best treatment paradigms with current medications, evaluating new treatments, understanding risk factors for poor outcomes, and determining the full spectrum of long-term outcomes. An exciting recent study evaluated the efficacy of combination treatment with hormonal therapy (ACTH or OCS) and vigabatrin, finding that short-term outcomes were improved in those receiving combination therapy. ${ }^{64} \mathrm{~A}$ second study investigating combination treatment is currently enrolling in the United States (NCT03347526), though some centers have already adopted dual treatment approaches. ${ }^{88}$ A team science approach to developing new animal models for IS was recently an initiative of Citizens United for Research in Epilepsy (CURE; https://www.cureepilepsy.org), leading to several new animal models. Ongoing studies seek to determine if transcranial direct stimulation, ${ }^{89}$ cannabidiol (CBD; NCT034211496), AQB-565 (a novel fusion peptide derived from ACTH), ${ }^{90}$ or CPP-115 (a vigabatrin analogue) ${ }^{91}$ could be effective. Future research may also address treatment of subpopulations, such as those without hypsarrhythmia, or hypsarrhythmia without clinical spasms, and also to determine the appropriate duration of treatment. A consistent theme in the research to date is that the most important opportunity to improve outcomes is rapid treatment with appropriate medication.

\section{Conflict of Interest}

K.G.K. reports other funding from Zogenix, West Therapeutics, Biomarin, Biocodex, and GW Pharma, and grants from Pediatric Epilepsy Research Fund, and Colorado Department of Public Health and Environment, outside the submitted work. R.M. reports grants from West Therapeutics, Inc and Pediatric Epilepsy Research Consortium (PERC), during the conduct of the study.

\section{References}

1 West W. On a particular form of infantile convulsions. Lancet 1841;1:724-725

2 Fisher RS, Cross JH, French JA, et al. Operational classification of seizure types by the International League Against Epilepsy: Position Paper of the ILAE Commission for Classification and Terminology. Epilepsia 2017;58(04):522-530

3 Lux AL, Osborne JP. A proposal for case definitions and outcome measures in studies of infantile spasms and West syndrome: consensus statement of the West Delphi group. Epilepsia 2004;45 (11):1416-1428

4 Trevathan E, Murphy CC, Yeargin-Allsopp M. The descriptive epidemiology of infantile spasms among Atlanta children. Epilepsia 1999;40(06):748-751

5 Jia JL, Chen S, Sivarajah V, Stephens D, Cortez MA. Latitudinal differences on the global epidemiology of infantile spasms: systematic review and meta-analysis. Orphanet J Rare Dis 2018;13(01):216
6 Cowan LD, Hudson LS. The epidemiology and natural history of infantile spasms. J Child Neurol 1991;6(04):355-364

7 Riikonen R. Epidemiological data of West syndrome in Finland. Brain Dev 2001;23(07):539-541

8 Kurokawa T, Goya N, Fukuyama Y, Suzuki M, Seki T, Ohtahara S. West syndrome and Lennox-Gastaut syndrome: a survey of natural history. Pediatrics 1980;65(01):81-88

9 Riikonen R, Donner M. ACTH therapy in infantile spasms: side effects. Arch Dis Child 1980;55(09):664-672

10 Bednarek N, Motte J, Soufflet C, Plouin P, Dulac O. Evidence of lateonset infantile spasms. Epilepsia 1998;39(01):55-60

11 Donat JF, Wright FS. Simultaneous infantile spasms and partial seizures. J Child Neurol 1991;6(03):246-250

12 Talwar D, Baldwin MA, Hutzler R, Griesemer DA. Epileptic spasms in older children: persistence beyond infancy. Epilepsia 1995;36 (02):151-155

13 Auvin S, Hartman AL, Desnous B, et al. Diagnosis delay in West syndrome: misdiagnosis and consequences. Eur J Pediatr 2012; 171(11):1695-1701

14 Hussain SA, Lay J, Cheng E, Weng J, Sankar R, Baca CB. Recognition of infantile spasms is often delayed: the ASSIST study. J Pediatr 2017;190:215-221.e1

15 Gibbs FA, Gibbs EL. Atlas of Electroencephalography. Reading, MA: Addison-Wesley; 1952

16 Hussain SA, Kwong G, Millichap JJ, et al. Hypsarrhythmia assessment exhibits poor interrater reliability: a threat to clinical trial validity. Epilepsia 2015;56(01):77-81

17 Mytinger JR, Hussain SA, Islam MP, et al. Improving the inter-rater agreement of hypsarrhythmia using a simplified EEG grading scale for children with infantile spasms. Epilepsy Res 2015; 116:93-98

18 Granström ML, Gaily E, Liukkonen E. Treatment of infantile spasms: results of a population-based study with vigabatrin as the first drug for spasms. Epilepsia 1999;40(07):950-957

19 Riikonen R. A long-term follow-up study of 214 children with the syndrome of infantile spasms. Neuropediatrics 1982;13(01):14-23

20 Demarest ST, Shellhaas RA, Gaillard WD, et al; Pediatric Epilepsy Research Consortium. The impact of hypsarrhythmia on infantile spasms treatment response: observational cohort study from the National Infantile Spasms Consortium. Epilepsia 2017;58(12): 2098-2103

21 Howitz P, Platz P. Infantile spasms and HLA antigens. Arch Dis Child 1978;53(08):680-682

22 Hrachovy RA, Frost JD Jr, Kellaway P. Hypsarrhythmia: variations on the theme. Epilepsia 1984;25(03):317-325

23 Sumanasena SP, Wanigasinghe J, Arambepola C, Sri Ranganathan $S$, Muhandiram E. Developmental profile at initial presentation in children with infantile spasms. Dev Med Child Neurol 2019;61 (11):1295-1301

24 O'Callaghan FJ, Lux AL, Darke K, et al. The effect of lead time to treatment and of age of onset on developmental outcome at 4 years in infantile spasms: evidence from the United Kingdom Infantile Spasms Study. Epilepsia 2011;52(07):1359-1364

25 O'Callaghan FJK, Edwards SW, Alber FD, et al; International Collaborative Infantile Spasms Study (ICISS) investigators. Vigabatrin with hormonal treatment versus hormonal treatment alone (ICISS) for infantile spasms: 18-month outcomes of an open-label, randomised controlled trial. Lancet Child Adolesc Health 2018;2(10):715-725

26 Knupp KG, Leister E, Coryell J, et al; Pediatric Epilepsy Research Consortium. Response to second treatment after initial failed treatment in a multicenter prospective infantile spasms cohort. Epilepsia 2016;57(11):1834-1842

27 Wang CJ, Jonas R, Fu CM, Ng CY, Douglass L. Quality-of-care indicators for infantile spasms. J Child Neurol 2013;28(01):13-20

28 Patel AD, Berg AT, Billinghurst L, et al. Quality improvement in neurology: Child neurology quality measure set: executive summary. Neurology 2018;90(02):67-73 
29 Pellock JM, Hrachovy R, Shinnar S, et al. Infantile spasms: a U.S. consensus report. Epilepsia 2010;51(10):2175-2189

30 Wilmshurst JM, Gaillard WD, Vinayan KP, et al. Summary of recommendations for the management of infantile seizures: Task Force Report for the ILAE Commission of Pediatrics. Epilepsia 2015;56(08):1185-1197

31 Paciorkowski AR, Thio LL, Dobyns WB. Genetic and biologic classification of infantile spasms. Pediatr Neurol 2011;45(06):355-367

32 Wirrell EC, Shellhaas RA, Joshi C, Keator C, Kumar S, Mitchell WG; Pediatric Epilepsy Research Consortium. How should children with West syndrome be efficiently and accurately investigated? Results from the National Infantile Spasms Consortium. Epilepsia 2015;56(04):617-625

33 Poulat AL, Lesca G, Sanlaville D, et al. A proposed diagnostic approach for infantile spasms based on a spectrum of variable aetiology. Eur J Paediatr Neurol 2014;18(02):176-182

34 Osborne JP, Lux AL, Edwards SW, et al. The underlying etiology of infantile spasms (West syndrome): information from the United Kingdom Infantile Spasms Study (UKISS) on contemporary causes and their classification. Epilepsia 2010;51(10):2168-2174

35 Salar S, Moshé SL, Galanopoulou AS. Metabolic etiologies in West syndrome. Epilepsia Open 2018;3(02):134-166

36 Mackay MT, Weiss SK, Adams-Webber T, et al; American Academy of Neurology; Child Neurology Society. Practice parameter: medical treatment of infantile spasms: report of the American Academy of Neurology and the Child Neurology Society. Neurology 2004;62 (10):1668-1681

37 Go CY, Mackay MT, Weiss SK, et al; Child Neurology Society; American Academy of Neurology. Evidence-based guideline update: medical treatment of infantile spasms. Report of the Guideline Development Subcommittee of the American Academy of Neurology and the Practice Committee of the Child Neurology Society. Neurology 2012;78(24):1974-1980

38 Hancock EC, Osborne JP, Edwards SW. Treatment of infantile spasms. Cochrane Database Syst Rev 2013;(06):CD001770

39 Knupp KG, Coryell J, Nickels KC, et al; Pediatric Epilepsy Research Consortium. Response to treatment in a prospective national infantile spasms cohort. Ann Neurol 2016;79(03):475-484

40 Low NL. Infantile spasms with mental retardation. II. Treatment with cortisone and adrenocorticotropin. Pediatrics 1958;22(06): 1165-1169

41 Sorel L, Dusaucy-Bauloye A. [Findings in 21 cases of Gibbs' hypsarrhythmia; spectacular effectiveness of ACTH]. Acta Neurol Psychiatr Belg 1958;58(02):130-141

42 Brunson KL, Eghbal-Ahmadi M, Baram TZ. How do the many etiologies of West syndrome lead to excitability and seizures? The corticotropin releasing hormone excess hypothesis. Brain Dev 2001;23(07):533-538

43 Jaseja H, Jaseja B, Badaya S, Tonpay P. Superior therapeutic efficacy of adrenocorticotrophic hormone (ACTH) in infantile spasms: emerging evidence. Epilepsy Behav 2012;25(02):250

44 Lux AL, Edwards SW, Hancock E, et al. The United Kingdom Infantile Spasms Study comparing vigabatrin with prednisolone or tetracosactide at 14 days: a multicentre, randomised controlled trial. Lancet 2004;364(9447):1773-1778

45 Baram TZ, Mitchell WG, Tournay A, Snead OC, Hanson RA, Horton EJ. High-dose corticotropin (ACTH) versus prednisone for infantile spasms: a prospective, randomized, blinded study. Pediatrics 1996;97(03):375-379

46 Hrachovy RA, Frost JD Jr, Kellaway P, Zion TE. Double-blind study of ACTH vs prednisone therapy in infantile spasms. J Pediatr 1983; 103(04):641-645

47 Hussain SA, Shinnar S, Kwong G, et al. Treatment of infantile spasms with very high dose prednisolone before high dose adrenocorticotropic hormone. Epilepsia 2014;55(01):103-107

48 Yi ZS, Wu HP, Yu XY, Chen Y, Zhong JM. Efficacy and tolerability of high-dose prednisone in Chinese children with infantile spasms. Brain Dev 2015;37(01):23-28
49 Gonzalez-Giraldo E, Stafstrom CE, Stanfield AC, Kossoff EH. Treating infantile spasms with high-dose oral corticosteroids: a retrospective review of 87 children. Pediatr Neurol 2018;87:30-35

50 Chiron C, Dulac O, Beaumont D, Palacios L, Pajot N, Mumford J. Therapeutic trial of vigabatrin in refractory infantile spasms. J Child Neurol 1991(Suppl 2):S52-S59

51 Vigevano F, Cilio MR. Vigabatrin versus ACTH as first-line treatment for infantile spasms: a randomized, prospective study. Epilepsia 1997;38(12):1270-1274

52 Appleton RE, Peters AC, Mumford JP, Shaw DE. Randomised, placebo-controlled study of vigabatrin as first-line treatment of infantile spasms. Epilepsia 1999;40(11):1627-1633

53 Elterman RD, Shields WD, Mansfield KA, Nakagawa J; US Infantile Spasms Vigabatrin Study Group. Randomized trial of vigabatrin in patients with infantile spasms. Neurology 2001;57(08):1416-1421

54 Lux AL, Edwards SW, Hancock E, et al; United Kingdom Infantile Spasms Study. The United Kingdom Infantile Spasms Study (UKISS) comparing hormone treatment with vigabatrin on developmental and epilepsy outcomes to age 14 months: a multicentre randomised trial. Lancet Neurol 2005;4(11):712-717

55 Chiron C, Dumas C, Jambaqué I, Mumford J, Dulac O. Randomized trial comparing vigabatrin and hydrocortisone in infantile spasms due to tuberous sclerosis. Epilepsy Res 1997;26(02):389-395

56 Hong AM, Turner Z, Hamdy RF, Kossoff EH. Infantile spasms treated with the ketogenic diet: prospective single-center experience in 104 consecutive infants. Epilepsia 2010;51(08):1403-1407

57 Glauser TA, Clark PO, Strawsburg R. A pilot study of topiramate in the treatment of infantile spasms. Epilepsia 1998;39(12):1324-1328

58 Zou LP, Lin Q, Qin J, Cai FC, Liu ZS, Mix E; Topiramate Study Group. Evaluation of open-label topiramate as primary or adjunctive therapy in infantile spasms. Clin Neuropharmacol 2008;31(02): 86-92

59 Weber A, Cole JW, Mytinger JR. Infantile spasms respond poorly to topiramate. Pediatr Neurol 2015;53(02):130-134

60 Angappan D, Sahu JK, Malhi P, Singhi P. Safety, tolerability, and effectiveness of oral zonisamide therapy in comparison with intramuscular adrenocorticotropic hormone therapy in infants with West syndrome. Eur J Paediatr Neurol 2019;23(01):136-142

61 Gümüş H, Kumandaş S, Per H. Levetiracetam monotherapy in newly diagnosed cryptogenic West syndrome. Pediatr Neurol 2007;37(05):350-353

62 Mikati MA, El Banna D, Sinno D, Mroueh S. Response of infantile spasms to levetiracetam. Neurology 2008;70(07):574-575

63 Auvichayapat N, Tassniyom S, Treerotphon S, Auvichayapat P. Treatment of infantile spasms with sodium valproate followed by benzodiazepines. J Med Assoc Thai 2007;90(09):1809-1814

64 O'Callaghan FJ, Edwards SW, Alber FD, et al; Participating Investigators. Safety and effectiveness of hormonal treatment versus hormonal treatment with vigabatrin for infantile spasms (ICISS): a randomised, multicentre, open-label trial. Lancet Neurol 2017; 16(01):33-42

65 Maguire MJ, Hemming K, Wild JM, Hutton JL, Marson AG. Prevalence of visual field loss following exposure to vigabatrin therapy: a systematic review. Epilepsia 2010;51(12):2423-2431

66 Westall CA, Wright T, Cortese F, Kumarappah A, Snead OC III, Buncic JR. Vigabatrin retinal toxicity in children with infantile spasms: an observational cohort study. Neurology 2014;83(24): 2262-2268

67 Schwarz MD, Li M, Tsao J, et al. A lack of clinically apparent vision loss among patients treated with vigabatrin with infantile spasms: the UCLA experience. Epilepsy Behav 2016;57(Pt A):29-33

68 Hussain SA, Tsao J, Li M, et al. Risk of vigabatrin-associated brain abnormalities on MRI in the treatment of infantile spasms is dosedependent. Epilepsia 2017;58(04):674-682

69 Fong CY, Osborne JP, Edwards SW, et al. An investigation into the relationship between vigabatrin, movement disorders, and brain magnetic resonance imaging abnormalities in children with infantile spasms. Dev Med Child Neurol 2013;55(09):862-867 
70 Fedak EM, Patel AD, Heyer GL, Wood EG, Mytinger JR. Optimizing care with a standardized management protocol for patients with infantile spasms. J Child Neurol 2015;30(10):1340-1342

71 Rajaraman RR, Lay J, Alayari A, Anderson K, Sankar R, Hussain SA. Prevention of infantile spasms relapse: zonisamide and topiramate provide no benefit. Epilepsia 2016;57(08):1280-1287

72 Chipaux M, Dorfmüller G, Fohlen M, et al. Refractory spasms of focal onset-a potentially curable disease that should lead to rapid surgical evaluation. Seizure 2017;51:163-170

73 Chugani HT, Ilyas M, Kumar A, et al. Surgical treatment for refractory epileptic spasms: the Detroit series. Epilepsia 2015; 56(12):1941-1949

74 Baba H, Toda K, Ono T, Honda R, Baba S. Surgical and developmental outcomes of corpus callosotomy for West syndrome in patients without MRI lesions. Epilepsia 2018;59(12):2231-2239

75 Glaze DG, Hrachovy RA, Frost JD Jr, Kellaway P, Zion TE. Prospective study of outcome of infants with infantile spasms treated during controlled studies of ACTH and prednisone. J Pediatr 1988; 112(03):389-396

76 Primec ZR, Kopac S, Neubauer D. Epidemiologic features of infantile spasms in Slovenia. Epilepsia 2002;43(02):183-187

77 Dulac O, Plouin P, Jambaqué I. Predicting favorable outcome in idiopathic West syndrome. Epilepsia 1993;34(04):747-756

78 Ito M, Aiba H, Hashimoto K, et al. Low-dose ACTH therapy for West syndrome: initial effects and long-term outcome. Neurology 2002;58(01):110-114

79 Hwang YS; Korean Child Neurology Society. National survey on West syndrome in Korea. Brain Dev 2001;23(07):565-569

80 Matsuo A, Matsuzaka T, Tsuru A, et al. Epidemiological and clinical studies of West syndrome in Nagasaki Prefecture, Japan. Brain Dev 2001;23(07):575-579

81 Lombroso CT. A prospective study of infantile spasms: clinical and therapeutic correlations. Epilepsia 1983;24(02):135-158
82 Rantala H, Putkonen T. Occurrence, outcome, and prognostic factors of infantile spasms and Lennox-Gastaut syndrome. Epilepsia 1999; 40(03):286-289

83 Matsumoto A, Watanabe K, Negoro T, et al. Infantile spasms: etiological factors, clinical aspects, and long term prognosis in 200 cases. Eur J Pediatr 1981;135(03):239-244

84 Sidenvall R, Eeg-Olofsson O. Epidemiology of infantile spasms in Sweden. Epilepsia 1995;36(06):572-574

85 Riikonen R, Amnell G. Psychiatric disorders in children with earlier infantile spasms. Dev Med Child Neurol 1981;23(06): 747-760

86 Askalan R, Mackay M, Brian J, et al. Prospective preliminary analysis of the development of autism and epilepsy in children with infantile spasms. J Child Neurol 2003;18(03):165-170

87 Wheless JW, Gibson PA, Rosbeck KL, et al. Infantile spasms (West syndrome): update and resources for pediatricians and providers to share with parents. BMC Pediatr 2012;12:108

88 Hussain SA. Treatment of infantile spasms. Epilepsia Open 2018;3 (Suppl 2):143-154

89 Yang D, Du Q Huang Z, et al. Transcranial direct current stimulation for patients with pharmacoresistant epileptic spasms: a pilot study. Front Neurol 2019;10:50

90 Chern CR, Chern CJ, Velíšková J, Velíšek L. AQB-565 shows promise in preclinical testing in the model of epileptic spasms during infancy: head-to-head comparison with ACTH. Epilepsy Res 2019; $152: 31-34$

91 Doumlele K, Conway E, Hedlund J, Tolete P, Devinsky O. A case report on the efficacy of vigabatrin analogue (1S, 3S)-3-amino-4difluoromethylenyl-1-cyclopentanoic acid (CPP-115) in a patient with infantile spasms. Epilepsy Behav Case Rep 2016;6:67-69

92 Scheffer IE, Berkovic S, Capovilla G, et al. ILAE classification of the epilepsies: position paper of the ILAE Commission for Classification and Terminology. Epilepsia 2017;58(04):512-521 